\title{
Critical pitting temperature on low temperature plasma carburized AISI 410 stainless steel
}
M. V. Garcia'
O. L. S. Ferreira ${ }^{2}$
M. A. C. Berton ${ }^{2}$
R. P. Cardoso'

\section{Abstract}

Low-temperature plasma assisted carburizing (LTPC) is an efficient method to provide improvement on surface mechanical properties of stainless steels, with a consequent improvement on its tribological behavior. The application of this treatment on martensitic stainless steels is recent and there are many aspects that deserves attention, including the treated surface corrosion resistance. Among various electrochemical techniques, critical pitting temperature (CPT) has been widely used to characterize stainless steels corrosion resistance due to its good reproducibility, sensitivity and efficiency. In this context, the purpose of this work was to apply LTPC thermochemical treatment on AISI 410 martensitic stainless steel, aiming to determine the influence of the treatment temperature in the treated surface microstructure, hardness and corrosion resistance employing TCP technique. The carburizing treatments were carried out at $300,350,400$ and $450{ }^{\circ} \mathrm{C}$ during 6 hours, using a gas mixture containing $99.5 \%$ of $\left(80 \% \mathrm{H}_{2}+20 \% \mathrm{Ar}\right)+0.5 \% \mathrm{de} \mathrm{CH}_{4}$ (in volume). The gas mixture flow rate and pressure were fixed at $1.67 \times 10^{-6} \mathrm{Nm}^{3} \mathrm{~s}^{-1}$ and 400 $\mathrm{Pa}$. The treated samples were characterized using X-ray diffractometry, optical microscopy, and microhardness measurements. The treated surfaces corrosion resistance was evaluated using OCP and CPT measurements. For the treated surfaces an increase in hardness and a displacement of XRD martensite peaks was observed, indicating that the carburizing processes were succeeded. The

1 Federal University of Paraná, Curitiba, Paraná, Brazil.

2 SENAI Institute of Innovation in Electrochemistry, Curitiba, Paraná, Brazil. 
electrochemical tests have shown that the untreated sample presented higher corrosion rate after pitting formation. Nevertheless, for temperatures below CPT it presented the lowest current density. The treatment temperature that provided the best corrosion behavior was that treated at $350{ }^{\circ} \mathrm{C}$, with corrosion current similar to the untreated sample before CPT. Results also indicated that there is a direct relationship between the LTPC temperature and the treated surface properties, especially corrosion resistance.

Keywords: Plasma assisted carburizing; Low-temperature carburizing; AISI 410 martensitic stainless steel; Corrosion resistance; Critical pitting temperature.

\section{Introduction}

Plasma assisted treatments tends to be specially recommended due its ecological advantages and so it has been applied on the field of surface treatments. There are many factors that makes plasma assisted processes economically advantageous, such as: quality of the treatments, low energy waste, low emission of pollutants, reproducibility of the results, etc (Suchentrunk et al., 1997).

As demonstrated by Edenhofer et al. (2001), “conventional” plasma carburizing $\left(\sim 900^{\circ} \mathrm{C}\right)$ can produce good results on steels surface treatment. For the special case of austenitic stainless steels, researches have shown that low-temperature carburizing (below $450{ }^{\circ} \mathrm{C}$ ) provides similar mechanical properties as those obtained in "conventional" carburizing without causing reduction on the treated surface corrosion resistance (Ernst et al., 2007; Gobbi et al., 2006; Souza et al., 2009; Sun, 2005; Sun, 2009). Low-temperature carburizing was also applied by Heuer et al. (2010) to achieve interstitial hardening of the PH13-8 Mo martensitic stainless steels. Through cyclic polarization curves, authors showed that when the treatment temperature is correctly set, the treatment increases the passivity of the surface when compared to the untreated surface.

Low-temperature plasma assisted carburizing (LTPC) of martensitic stainless steels (MSS) is a relatively recent topic. In the case of MSS, LTPC aims to introduce carbon in solid solution into the treated surface, forming the expanded martensite phase that provides an improvement on the steel surface mechanical properties. Scheuer (2015) shows improvement on mechanical properties and possible gain on the corrosion resistance of low-temperature plasma assisted carburized AISI 420 surfaces. As in Heuer et al. (2010), Scheuer (2015) also shows that when the 
treatment is performed at high temperatures or for too long times it depletes the corrosion resistance of the treated surface.

When treating a stainless steel corrosion resistance is an important issue, pitting corrosion is one of the most important types of corrosion in this class of steel. Burstein (1993) described the nucleation and growth of corrosion pits on stainless steels. Electrochemical measurements are important tools to study types of corrosion. One of them, the critical pitting temperature (CPT), was introduced by Brigham and Tozer and has been defined as the temperature below which pitting will not initiate and above which pits will initiate on stainless steel exposed to oxidizing chloride solution (Brigham, 1975).

Below the CPT the steel will not pit "regardless of potential and exposure time, and the breakdown observed at high anodic potentials it is caused by transpassive dissolution" (Zhang, 2012). When the temperature is higher than CPT, stable pitting occurs and breakdown potentials decreases below those required for transpassivity. CPT depends on alloy elements (Pardo, 2008) and hardly depends on chloride concentration within a lower concentration range (Ernst, 2007). Among several electrochemical techniques, CPT is considered good to detect pitting propagation in stainless steels due to the reproducibility, sensitivity and efficiency that this technique offers (Deng et al., 2009). CPT has been applied on austenitic stainless steel such as works of Zakeri (2014) and Liu (2015). Nevertheless, on MSS, especially on MSS carburized surfaces, the application of CTP was not yet explored and will be the main subject of this work.

So, the aim of the present work is to apply LTPC on the AISI 410 MSS, studying the treated surface microstructure, hardness and corrosion resistance.

\section{Experimental procedure}

AISI 410 MSS cylindrical samples of $20 \mathrm{~mm}$ in height and $9.5 \mathrm{~mm}$ in diameter, and also samples of 2 inch in diameter and $10 \mathrm{~mm}$ in height, were cut from commercial rods. Then, samples were austenitized at $1010{ }^{\circ} \mathrm{C}$ for $1 \mathrm{~h}$ and air cooled, according to the ASTM (1991) recommendation. After this heat treatment samples presented a hardness of $410 \mathrm{HV}_{0.3}$. Before LTPC, heat treated samples were ground, polished, cleaned in ultrasonic bath using ethyl alcohol and introduced into the LTPC apparatus (Figure 1). It is important to emphasize that tempering and carburizing were simultaneously carried out inside this chamber. 


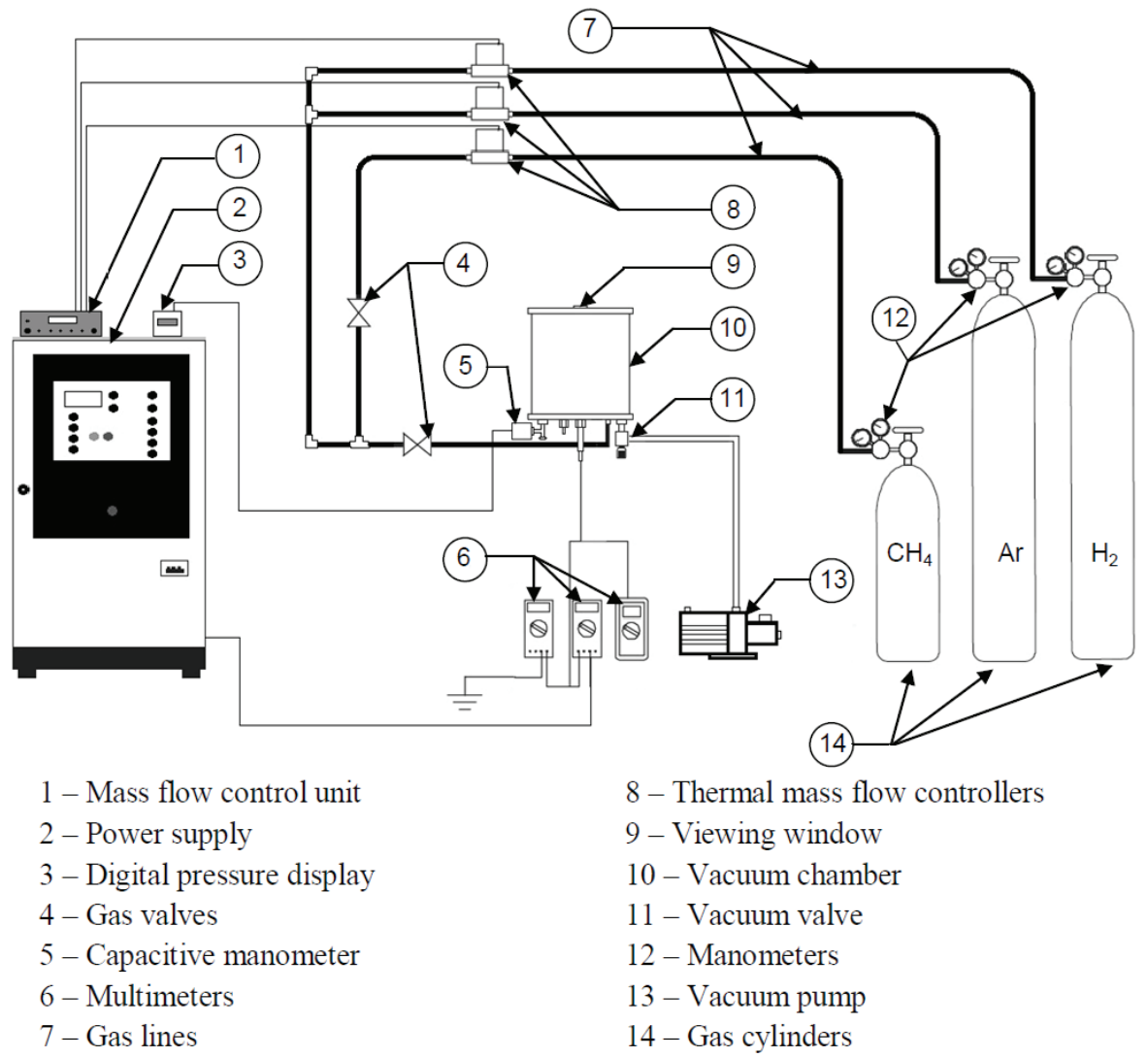

Figure 1 LTPC experimental apparatus.

Source: Schever, 2011

Aiming to remove the native oxide layer from sample surface, in order to assure the $\mathrm{C}$ diffusion into the substrate, specimens were plasma sputter-cleaned in a gas mixture of $80 \% \mathrm{H}_{2}+20 \% \mathrm{Ar}$, under a pressure of $400 \mathrm{~Pa}$, at $300{ }^{\circ} \mathrm{C}$ for 0.5 $\mathrm{h}$ before LTPC. After that, LTPC was carried out using a gas mixture containing $99.5 \%\left(80 \% \mathrm{H}_{2}+20 \% \mathrm{Ar}\right)+0.5 \% \mathrm{CH}_{4}$, in volume, and total gas flow rate, pressure and voltage were fixed at $1.67 \times 10^{-6} \mathrm{~m}^{3} \mathrm{~s}^{-1}, 400 \mathrm{~Pa}$ and $700 \mathrm{~V}$, respectively. These treating conditions were fixed according to Scheuer (2012) and treatments were carried out in the same experimental apparatus applied by Scheuer (2012). The treatment time was fixed at $6 \mathrm{~h}$ and the studied carburizing temperatures were $300,350,400$ and $450^{\circ} \mathrm{C}$.

Treated samples were characterized by microstructural analysis, surface hardness measurements (using a Shimadzu HMV-2T equipment) and X-ray diffractometry (XRD). For microstructural analysis, crossectioned samples were 
ground and mechanically polished using abrasive suspension $\mathrm{Al}_{2} \mathrm{O}_{3}$ containing $1 \mu \mathrm{m}$ particles, following the procedure described by Vander Voort and James (1992). The optical microscopic observations were made after etching samples with Villela (1 $\mathrm{g} \mathrm{C}_{6} \mathrm{H}_{3} \mathrm{~N}_{3} \mathrm{O}_{7}+5 \mathrm{ml} \mathrm{HCl}+100 \mathrm{ml}$ alcohol) during 30 seconds.

To determine the phases present in the treated layers X-ray diffractometry (XRD) was used and the measurements were made with a $\mathrm{CuKa}$ radiation in Bragg-Brentano configuration. The scanning range was from 30 to $90^{\circ}$ and the scanning rate was $1 \% \mathrm{~min}$. The observed phases were identified through comparison of the diffraction patterns with reference patterns obtained on JCPDS - "Joint Committe on Powder Diffraction Standards" and other works on LTPC of MSS.

OCP measurements were carried out on a three electrode electrochemical cell: counter-electrode (CE) made of a platinum; working electrode (WE), which was the sample itself; and the reference electrode (RE), which was a $\mathrm{Ag} / \mathrm{AgCl} 3 \mathrm{M}$ $\mathrm{KCl}$ reference electrode. The electrolyte was a $3.5 \% \mathrm{NaCl}$ deionized water solution. The electrochemical cell consisted of a $30 \mathrm{~mm}$ height and $25 \mathrm{~mm}$ in diameter PVC tube attached on the treated sample surface. Sample/cell interface was sealed using epoxy glue. An electrochemical cell scheme is shown on Figure 2.

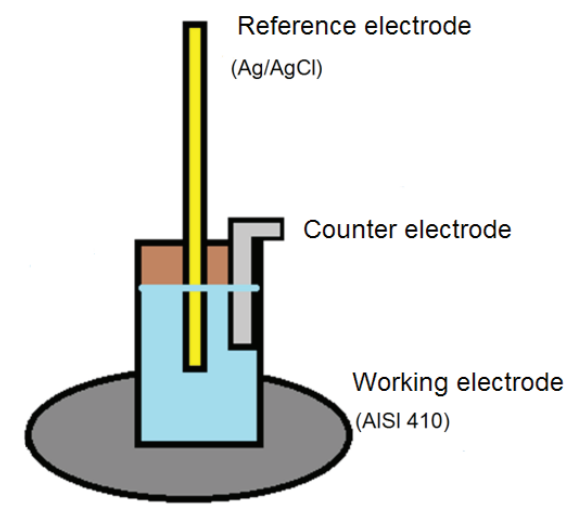

Figure 2 Electrochemical cell scheme.

OCP was measured during an hour, in order to reach steady state. The tests were carried out at room temperature and an Autolab potentiostat (model PGSTAT302N) was used to perform de measurements.

Finally, the CPT tests were performed. For this test $9.5 \mathrm{~mm}$ diameter samples were used. The test solution was $1 \mathrm{M} \mathrm{NaCl}(5.85 \%)$. For each testing temperature $\left(30-55^{\circ} \mathrm{C}\right.$, in steps of $\left.5{ }^{\circ} \mathrm{C}\right)$, the specimen was allowed to stabilize at open circuit potential (OCP) for $30 \mathrm{~min}$, then a potential of OCP $+100 \mathrm{mV}$ was applied for $1 \mathrm{~min}$ and the current was recorded. The counter electrode was a carbon bar, the 
reference electrode was $\mathrm{Ag} / \mathrm{AgCl} 3 \mathrm{M} \mathrm{KCl}$, and the working electrode was the sample itself.

\section{Results and discussion}

\subsection{Treated surface microstructure and hardness}

Figure 3 shows surface hardness values of the treated surface (top - exposed to the plasma) and untreated surface (bottom - in contact with the sample holder, not exposed to the plasma) for all the studied LTPC conditions. Comparing the measurements obtained on the treated surface (top) to the untreated surface (bottom), it can be observed that the treated surface hardness is clearly increased for the samples carburized at 350,400 e $450^{\circ} \mathrm{C}$, indicating that LTPC altered the treated surface. The untreated surface hardness presented non-significant hardness variation in respect to sample hardness prior to LTPC, as expected according to ASTM (1991) for the tempering of the AISI 410 MSS (remerging that in this work LTPC and tempering occurs simultaneously).

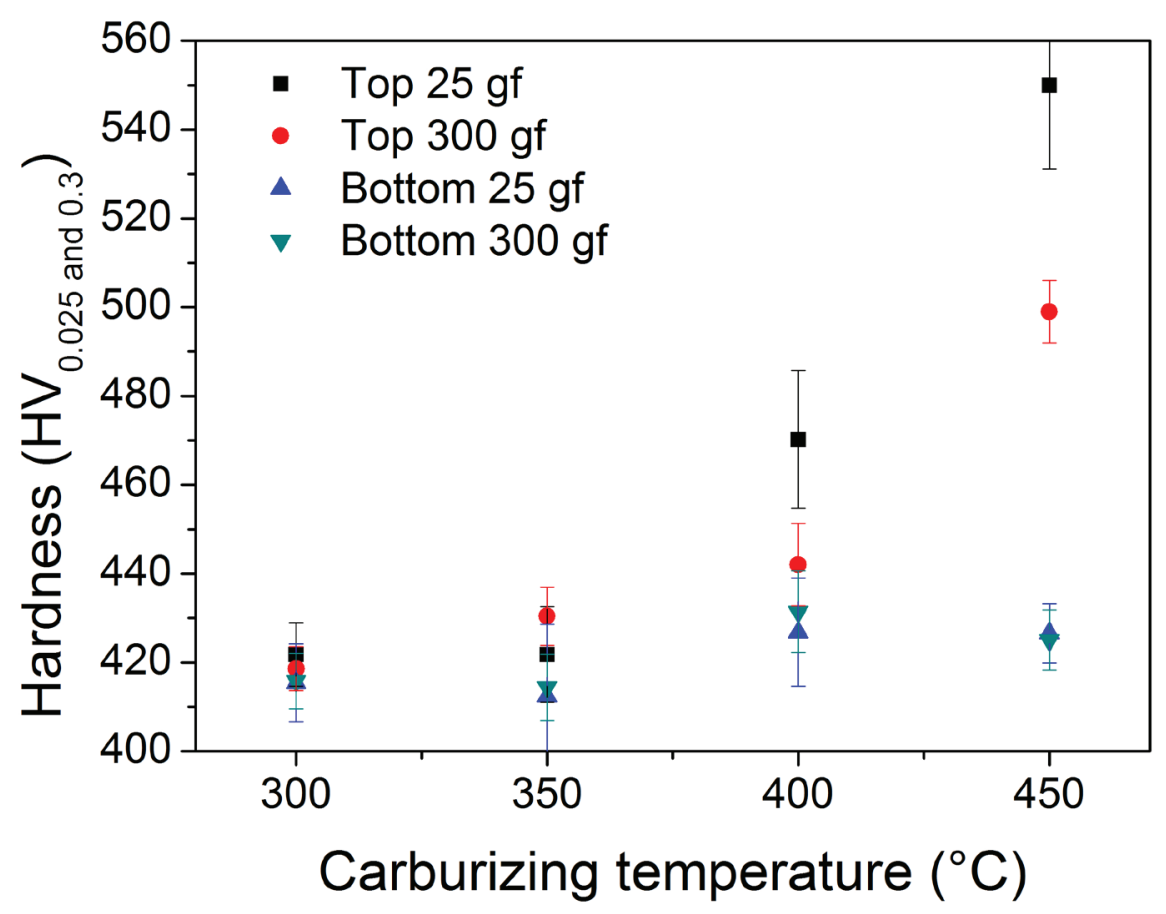

Figure 3 Treated surface (top) and untreated surface (bottom) hardness measurements using $25 \mathrm{gf}$ and $300 \mathrm{gf} \mathrm{load}$. 
In Scheuer (2012) the microhardness values measured on the treated surfaces of AISI 420 MSS LTPC samples (treated at the same conditions, but for a shorter time $(4 \mathrm{~h})$ were considerably higher than the presented here, probably due to the difference in the substrate composition.

The cross-section micrographs of carburized samples are presented in Figure 4, the carburized layer is not revealed and no sensitization is observed. Besides the etch with Villela during $30 \mathrm{~s}$, samples were also immersed in $10 \%$ Nital solution for 10 min and no etching was observed, confirming the absence of sensitization.
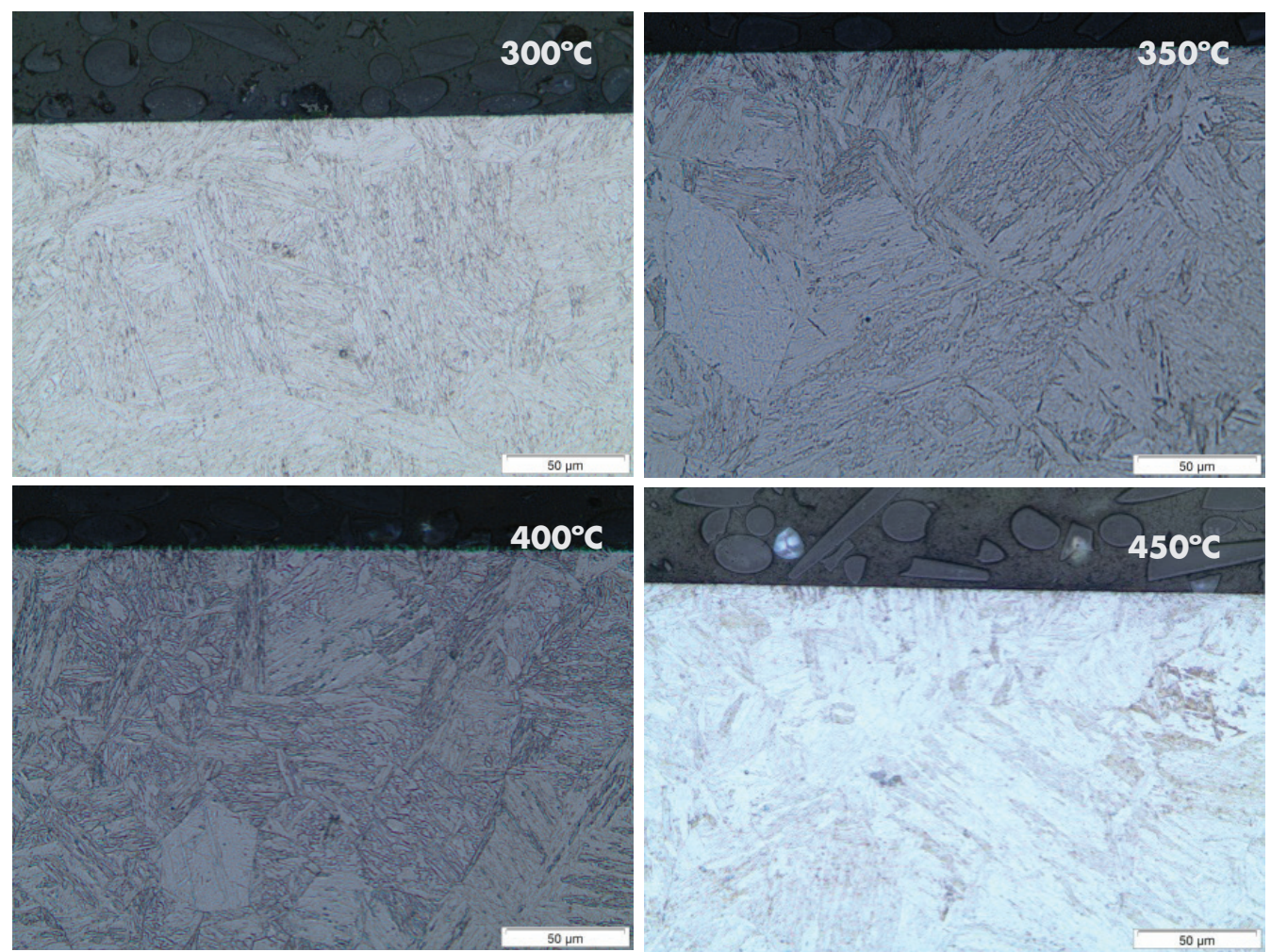

Figure 4 Cross-section micrographs for LTPC samples treated at different temperatures etched with Villela for $30 \mathrm{~s}$.

XRD measurements, presented in Figure 5, indicated that after treatment $\mathrm{Fe}_{3} \mathrm{C}$ and expanded-martensite are formed on the treated surface. The formation of expanded martensite is characterized by the shift of the diffraction peak for low angles, and Figure 6 shows the referred peak shift in detail, which suggests that the treated surface is enriched by carbon as expected for LTPC, in agreement with the hardness values presented in Figure 3. 


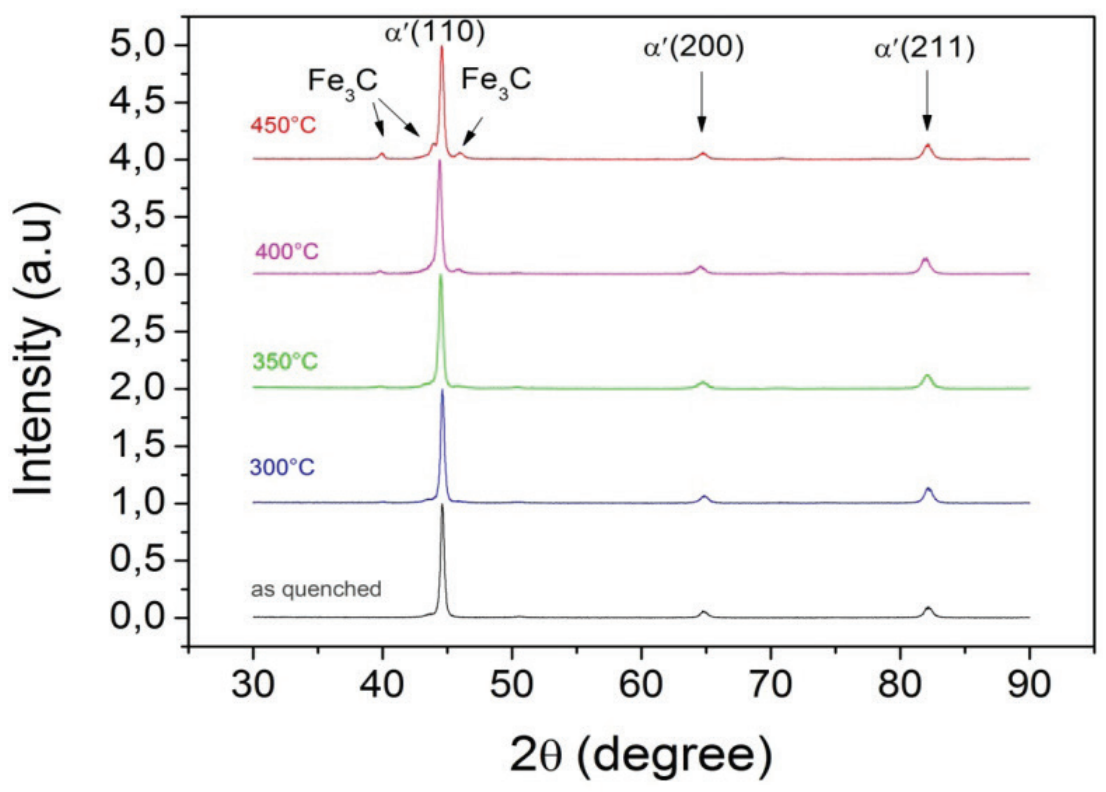

Figure 5 XRD patterns for as-quenched (untreated) sample and for samples treated at different temperatures.

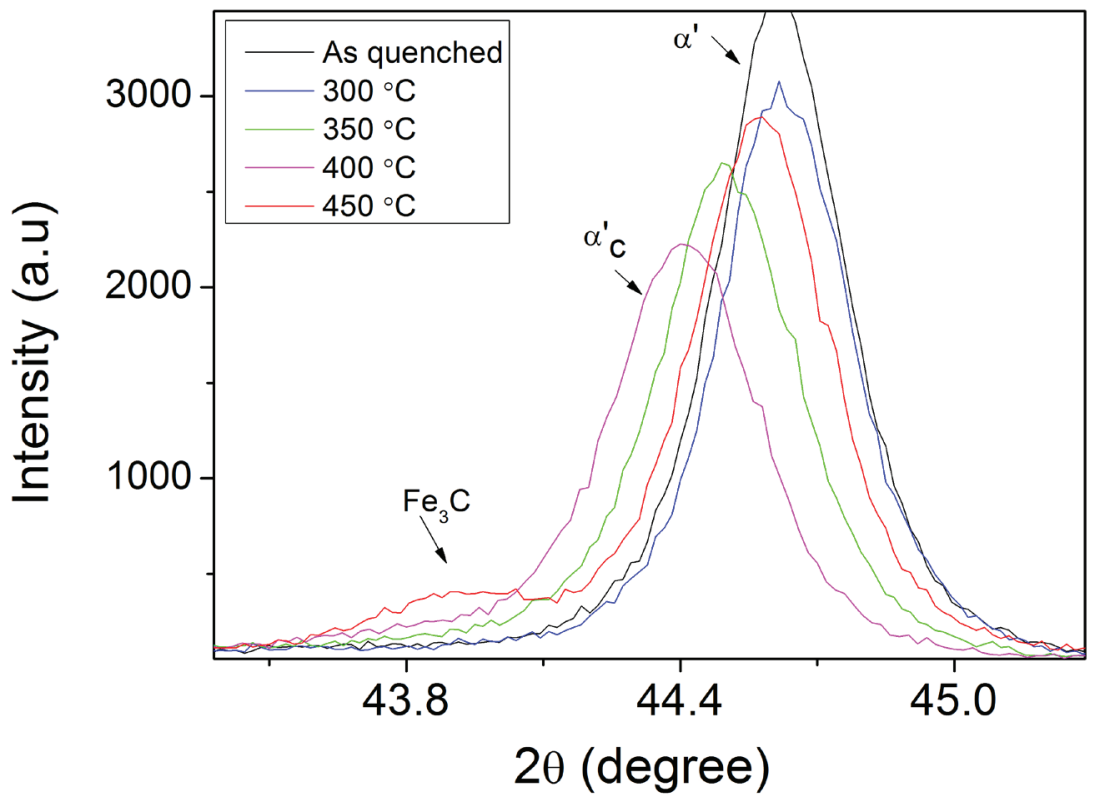

Figure 6 Detail of the XRD patterns for as-quenched (untreated) sample and for samples treated at different temperatures. 


\subsection{Treated surface corrosion resistance}

The OCP results showed on Figure 7 suggests the dissolution of the passive layer with a reduction of OCP as a function of the immersion time. It indicates also that OCP is dependent of the LTPC parameters, and consequently of the treated surface microstructure.

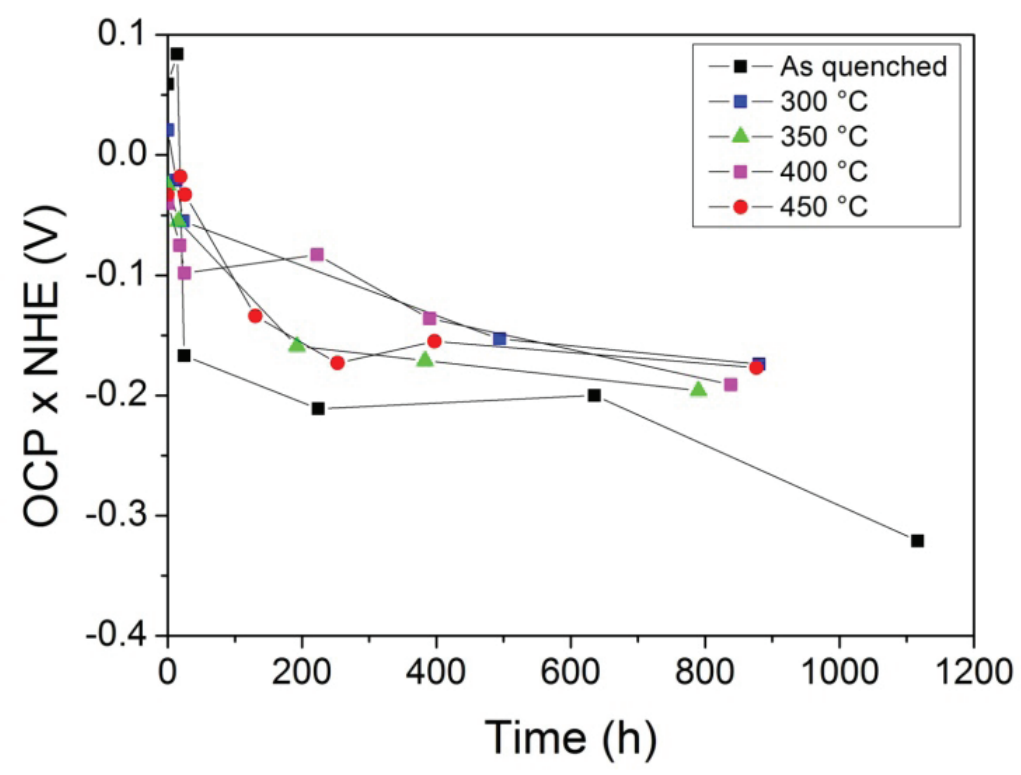

Figure 7 OCP versus time.

For MSS, the corrosion resistance enhancement after nitriding has been associated to the compound layer (Corengia et al., 2004; Li and Bell, 2006 and 2007), but for LTPC of MSS the subject is not yet well understood. In this present work, the treated samples higher values of OCP, compared to the non-treated sample, is attributed to the formation of the carburized layer $\left(\alpha_{c}^{\prime}+\mathrm{Fe}_{3} \mathrm{C}\right)$ as in Scheuer (2015). This layer in this present work is not clearly seen by optical microscopy, but its existence was indicated by XRD patterns and hardness measurements. Additionally, the corrosion properties enhancement (or at least its maintenance) after carburizing can be indirectly inferred by the absence of sensitization evidences.

Figure 8 presents CPT results, showing stable current density (or current measured after $60 \mathrm{~s}$ on the test temperature) as a function of the test temperature for each LTPC studied condition. It can be observed that, after pitting occurrence, as-quenched samples presents the highest current density, indicating higher corrosion rate, but before pitting occurrence, it has the lowest current density among all samples tested. It is possible that the carburized layer influences on the nucleation 
or growth mechanisms, mentioned by Bustein (1993), delaying the stable pitting growth. So, a possible alteration on the pitting nucleation and growth mechanism might explain the difference of current of the as quenched sample and LTPC samples after reaching the CPT. Among the treated samples, that treated at 350 ${ }^{\circ} \mathrm{C}$ presented the lowest current density for all temperatures, indicating higher corrosion resistance.

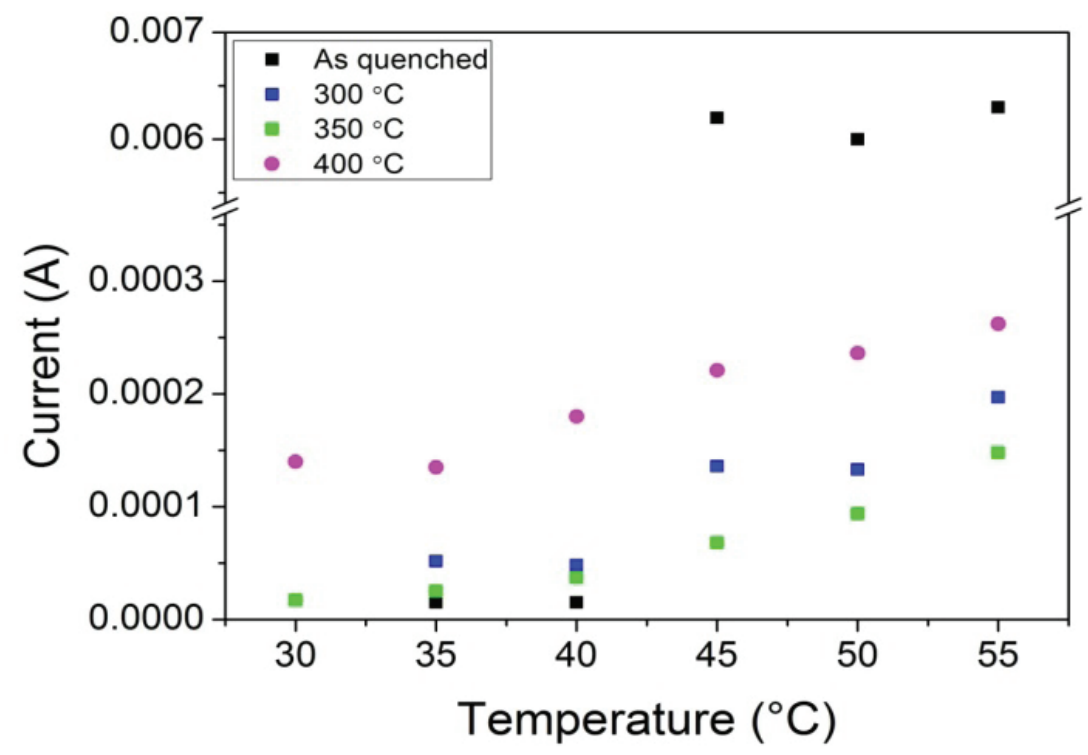

Figure 8 Current versus Temperature for all samples submitted to CPT test.

\section{Conclusions}

Experiments were carried in order to determine the influence of the treatment temperature on the corrosion resistance of LTPC of AISI 410 MSS, and the following conclusions can be listed:

i) LTPC can be successfully applied to improve surface hardness of AISI 410 without losing corrosion resistance;

ii) No-evidences of the diffusion layer was observed on the micrographs, but its occurrence was confirmed by hardness measurements and XRD;

iii) There is no sensitization of the treated surface for the studied temperatures and time;

iv) XRD patterns showed that after LTPC expanded martensite and low intensity peaks of cementite are obtained on treated surface, and that at $450{ }^{\circ} \mathrm{C}$ the expanded martensite begins to decompose; 
v) OCP values indicates that OCP is dependent on carburizing process conditions (carburized layer's microstructure) and that LTPC tends to make the surface nobler; and

vi) CPT results showed that as quenched samples presents higher current density after the occurrence of pitting and that, among carburized samples, that treated at $350^{\circ} \mathrm{C}$ provided the best corrosion behavior.

\section{Acknowledgements}

The authors wish to acknowledge CNPq and PRH-24 for the financial support and also express their thanks to SENAI/ISI and LORXI/UFPR for providing support for the samples characterization.

\section{References}

ASTM. Heat Treating of Stainless Steels. In; ASM International. ASTM Handbook; heat treating, v. 4, 1991.

BRIGHAM, R.J. Effect of $\mathrm{Cr}$ on the pitting resistance of austenitic stainless steels. In: Corrosion Science, 1975. v. 15, p. 579- 580.

BURSTEIN,G.T.; PITORIUS,P.C.; MATTIN, S.P. The nucleation and growth of corrosion pits on stainless steel. In: Corrosion Science, 1993. v. 35, n.1-4, p. 57-62.

CORENGIA, P.; YBARRA, G.; MOINA, C.; CABO, A.; BROITMAN, E. Microstructure and corrosion behavior of DC-pulsed plasma nitride AISI 410 martensitic stainless steel. In: Surface and Coatings Technology, 2004. v. 187, p. 63-69.

DENG, B.; WANG, Z.; JIANG, Y.; WANG, H.; GAO, J.; LI, J. Evaluation of localized corrosion in duplex stainless steel aged at $850^{\circ} \mathrm{C}$ with critical pitting temperature measurement. In: Electrochimica Acta, 2009. v. 54, p. 2790-2794.

ERNST, F.; CAO, Y.; MICHAL, G.M.; HEUER, A.H. Carbide precipitation in austenitic stainless steel carburized at low temperature. In: Acta Materialia, 2007. v. 55, p. 1895-1906.

ERNST, P.; NEWMAN, R. Explanationoftheeffectof high chloride concentration on the critical pitting temperature of stainless steel. In:Corrosion Science, 2007. p. 3705-3715. 
GOBBI, S.J.; SANTOS, C.B.; JACQUES, R.; TEISCHMANN, L.; STROHECKER, T.R.; ZOPPASFERREIRA, J. Endurecimento superficial dos aços AISI 316L e AISI 304 por cementação a plasma em baixas temperaturas. In: $17^{\circ} \mathrm{CBECIMat}$ - CONGRESSO BRASILEIRO DE ENGENHARIA E CIÊNCIA DOS MATERIAIS, Foz do Iguaçu, PR, Brasil, 2006.

HEUER, A.H.; KAHN, A.; O’DONNELL, L.J.; ERNST, F.; MICHAL, G.M.; RAYNE, R.J.; MARTIN, F.J.; NATISHAN, P.M. Carburization-Enhanced Passivity of PH13-8 Mo: A Precipitation-Hardened Martensitic Stainless Steel. In: Electrochemical and Solid-State Letters, 2010. v. 13 (12), p. C37-C39.

LI, C.X.; BELL, T. A comparative study of low temperature plasma nitriding, carburising and nitrocarburising of AISI 410 martensitic stainless steel. In: Materials Science and Technology, 2007. v. 23, n. 3, p. 355-361.

LI, C.X.; BELL, T. Corrosion properties of plasma nitrided AISI 410 martensitic stainless steel in $3.5 \% \mathrm{NaCl}$ and $1 \% \mathrm{HCl}$ aqueous solutions. In: Corrosion Science, 2006. v. 48, p. 2036-2049.

LIU, J.; ZHANG, T.; MENG, G.; SHAO, Y.; WANG, F. Effect of pitting nucleation on critical pitting temperature of $316 \mathrm{~L}$ stainless steel by nitric acid passivation. In: Corrosion Science, 2015. v. 91, p. 232-244.

PARDO, A.; MERINO, M.; COY, A.; VIEJO, F.; ARRABAL, R.; MATYKINA, E. Pitting corrosion behaviour of austenitic stainless steels - combining effects of Mn and Mo additions. In: Corrosion Science, 2008. v. 50, p. 1796-1806.

SCHEUER, C.J.; CARDOSO, R.P.; PEREIRA, R.; MAFRA, M.; BRUNATTO, S. F. Low temperature plasma carburizing of martensitic stainless steel. In: Materials Science and Engineering, 2012. A. 539, p. 369-372.

SCHEUER, Cristiano José. Comportamento tribológico e resistência à corrosão do aço inoxidável martensítico AISI 420 cementado por plasma a baixa temperatura. Tese (Doutorado em engenharia mecânica) - Universidade Federal do Paraná, Curitiba, 2015.

SOUZA, R.M.; IGNAT, M.; PINEDO, C.E.; TSCHIPTSCHIN, A.P. Structure and properties of low temperature plasma carburized austenitic stainless steels. In: Surface and Coatings Technology, 2009. v. 204, pp. 1102-1105. 
SUCHENTRUNK, R.; STAUDIGL, G.; JONKE, D.; FUESSER, H.J. Industrial applications for plasma processes-examples and trends. In: Surface and Coatings Technology, 1997. v. 97, p. 1-9.

SUN, Y. Kinetics of low temperature plasma carburizing of austenitic stainless steels. In: Journal of Materials Processing Technology, 2005. v. 168, p. 189-194.

SUN, Y. Response of cast austenitic stainless steel to low temperature plasma carburizing.In: Materials and Design, 2009. v. 30, p. 1377-1380.

VANDER VOORT, G. F.; JAMES, H. M. Wrought Stainless Steels, in ASM Handbook - Metallography and Microstructures, Ed. ASM International, p. 279$-296,1992$.

ZAKERI, M.; NAKHAIE, M.; NAGHIZADEH, M.; MOAYED, M.H. The effect of dichromate ín on the pitting corrosion of AISI 316L satinless steel. Part I: Critical pitting temperature.In: Corrosion Science, 2015. v. 93, p. 234-241.

ZHANG, T.; WANG, D.; SHAO, Y.; MENG, G.; WANG, F. A new criterion to determine the critical pitting temperature (CPT) based on electrochemical noise measurement. In: Corrosion Science, 2012. v. 58, p. 202-210. 
